\title{
ANALISIS KEBUTUHAN DAN KAPASITAS AREA PARKIR DI AREAL PERBELANJAAN KOTA SURAKARTA
}

\author{
Sumina \\ Program Studi Teknik Sipil, Fakultas Teknik, Universitas Tunas Pembangunan, Surakarta \\ minasumina33@gmail.com \\ Eny Krisnawati \\ Program Studi Arsitektur, Fakultas Teknik, Universitas Tunas Pembangunan, Surakarta \\ enykrisnawati4@yahoo.com
}

\begin{abstract}
Abstrak
Analisis ini bertujuan untuk mendapatkan gambaran tentang karakteristik parkir dalam Mall Solo Square Surakarta. Data yang digunakan adalah data primer yaitu pencatatan waktu masuk dan keluarnya kendaraan. Data sekunder yang dipakai adalah luas areal parkir, tipe parkir, dan kapasitas parkir. Metode yang diterapkan dalam analisis ini adalah dengan malakukan survei langsung di lapangan. Dari data kendaraan dilakukan analisis untuk mendapatkan karakteristik parkir berupa, akumulasi parkir, volume parkir, indeks parkir, tingkat turnover, durasi parkir, kebutuhan ruang parkir. Berdasarkan analisis karakteristik parkir di Mall Solo Square ini yaitu akumulasi maksimum harian tertinggi pada rentang waktu 15 menit untuk mobil sebanyak 595 kendaraan, untuk sepeda motor 758. Rata-rata volume harian untuk mobil adalah 1583 kendaraan, adapun untuk sepeda motor adalah 2381 kendaraan. Indeks parkir maksimum untuk mobil adalah 108,58\%, serta untuk sepeda motor adalah $112,40 \%$. Rata-rata tingkat turnover parkir mobil adalah $2,89 \mathrm{kend} / \mathrm{hari} / \mathrm{ruang}$, serta untuk sepeda motor adalah 2,14 kend/hari/ruang. Rata-rata durasi parkir harian tertinggi untuk mobil adalah 77,108 menit, serta untuk sepeda motor adalah 70,644 menit. Kebutuhan ruang parkir untuk mobil dengan melihat akumulasi maksimum adalah sebesar 595 kendaraan dengan luas area parkir $7437,5 \mathrm{~m}^{2}$, sedangkan luas area parkir tersedia $17432 \mathrm{~m}^{2}$, dengan demikian area parkir untuk mobil di Mall Solo Square masih memenuhi standar kebutuhan parkir. Kebutuhan ruang parkir untuk sepeda motor dengan melihat akumulasi maksimum adalah sebesar 852 kendaraan dengan luas area parkir $1278 \mathrm{~m}^{2}$, sedangkan luas area parkir tersedia $2365 \mathrm{~m}^{2}$, dengan demikian area parkir untuk mobil penumpang dan sepeda motor di Mall Solo Square masih memenuhi standar kebutuhan parkir. Jadi secara keseluruhan area parkir di Mall Solo Square masih mampu memenuhi kebutuhan parkir.
\end{abstract}

Kata kunci: Karakteristik parkir, Kapasitas, dan Kebutuhan Ruang Parkir

\begin{abstract}
This analysis aims to obtain an overview of the characteristics of parking in Solo Square Mall Surakarta. The data used are primary data, namely recording the time of entry and exit of the vehicle. Secondary data used are parking area, parking type, and parking capacity. The method applied in this analysis is to conduct direct surveys in the field. From the vehicle data, an analysis was carried out to obtain parking characteristics in the form of parking accumulation, parking volume, parking index, turnover rate, parking duration, and parking space requirements. Based on the analysis of parking characteristics at Solo Square Mall, it is the highest daily maximum accumulation in the span of 15 minutes for cars as many as 595 vehicles, for motorbikes 758 . The average daily volume for cars is 1583 vehicles, while for motorbikes is 2381 vehicles. The maximum parking index for cars is $108.58 \%$, and for motorbikes is $112.40 \%$. The average car park turnover rate is 2.89 vehicles / day / space, and for motorbikes it is 2.14 vehicles / day / space. The highest average daily parking duration
\end{abstract}


for cars is 77.108 minutes, and for motorbikes is 70.644 minutes. The need for parking space for cars by looking at the maximum accumulation is 595 vehicles with a parking area of $7437.5 \mathrm{~m} 2$, while the available parking area is $17432 \mathrm{~m} 2$, thus the parking area for cars in Solo Square Mall still meets the standard parking needs. The need for parking space for motorbikes by looking at the maximum accumulation is 852 vehicles with a parking area of $1278 \mathrm{~m} 2$, while the available parking area is $2365 \mathrm{~m} 2$, thus the parking area for passenger cars and motorbikes in Solo Square Mall still meets the standard of parking needs. So overall the parking area at Solo Square Mall is still able to meet parking needs.

Keywords: Parking characteristics, capacity, and parking space requirements

\section{PENDAhUluan}

Salah satu pusat perbelanjaan yang cukup besar di Kota Surakarta yaitu Mall Solo Square, berada di sekitar Jalan Brigjend Slamet Riyadi 451-455 Surakarta. Letak Mall Solo Square berada di Jalan Brigjend Slamet Riyadi yang merupakan salah satu jalan arteri yang ada di Kota Surakarta memungkinkan terjadi kepadatan lalu lintas pada jam-jam sibuk. Maka dari itu perlu dilakukan evaluasi apakah lahan parkir yang disediakan pihak pusat perbelanjaan tersebut dapat menampung kendaraan pribadi, baik roda empat atau roda dua pengunjung di mall Solo Square. Sehingga kendaraan yang ingin masuk ke pusat perbelanjaan tersebut parkir di tempat parkir yang telah disediakan dan tidak mengganggu arus lalu lintas yang ada di Jalan Brigjend Slamet Riyadi.

Pada analisis kebutuhan parkir ini menggunakan pedoman yang telah disusun oleh pemerintah. Pedoman yang dipakai adalah pada peraturan atau pedoman standar yang mengatur penyelenggaraan fasilitas parker, yaitu Pedoman Teknis Penyelengaraan Fasilitas Parkir Direktorat Jendral Perhubungan Darat Tahun 1996.
Menurut Pedoman Teknis Penyelenggaraan Fasilitas Parkir, Direktorat Jenderal Perhubungan Darat (1996) menyatakan bahwa Parkir adalah suatu keadaan tidak bergerak dari suatu kendaraan yang tidak bersifat sementara. Sedangkan berhenti adalah keadaan tidak bergerak dari suatu kendaraan yang bersifat sementara, dengan pengemudi tidak meninggalkan kendaraannya.

\section{TINJAUAN PUSTAKA}

\section{A. PENGERTIAN PARKIR}

Parkir adalah memangkalkan/menempatkan dengan memberhentikan kendaraan angkutan orang/barang (bermotor/tidak bermotor) pada suatu tempat parkir dalam jangka waktu tertentu (Dayana, 2012). Parkir menurut kamus besar Bahasa Indonesia merupakan tempat menaruh kendaraan dalam jangka waktu tertentu. Ada juga pengertian parkir dari Wikipedia yaitu keadaan tidak bergerak suatu kendaraan yang bersifat sementara karena ditinggalkan oleh pengemudinya.

Berdasarkan definisi diatas maka dapat ditarik kesimpulan bahwa parkir adalah keadaan berhenti/tidak bergerak suatu kendaraan bermotor 
maupun tidak bermotor karena ditinggalkan pemiliknya/pengemudinya di suatu tempat yang khusus dalam jangka waktu tertentu tergantung keperluan pemiliknya/pengemudinya.

\section{B. JENIS FASILITAS PARKIR}

Menurut Pedoman Teknis Penyelenggaraan Fasilitas Parkir, Direktorat Jendral Perhubungan Darat fasilitas parkir tahun 1996 ada dua jenis fasilitas parkir yaitu:

1. Parkir di badan jalan (on street parking)

Parkir di badan jalan adalah fasilitas parkir yang menggunakan pinggir atau tepi badan jalan. Parkir jenis ini memiliki kekurangan yaitu bisa menghambat arus lalu lintas karena pinggir jalan digunakan untuk keluar atau masuk kendaraan yang akan parkir.

2. Parkir di luar badan jalan (off street parking) Parkir di luar badan jalan adalah fasilitas parkir kendaraan yang tidak berada pada badan atau pun pinggir jalan tetapi berada pada luar badan jalan yang disediakan khusus.

\section{STATUS PARKIR}

Menurut Undan-undang Lalu lintas No.272/1996 status parkir dapat dikelompokkan menjadi:

1. Parkir Umum, Parkir umum adalah perparkiran yang menggunakan tanah-tanah, jalan lapangan yang dimiliki/dikuasai dan pengelolanya diselenggarakan oleh pemerintah daerah.

2. Parkir Khusus, Parkir khusus adalah perparkiran yang menggunakan tanah-tanah yang dikuasai dan pengelolanya diselenggarakan oleh pihak ketiga.

3. Parkir DaruratParkir darurat adalah perparkiran di tempat-tempat umum baik yang menggunakan tanah-tanah, jalan ataupun lapangan milik atau penguasaan Pemerintah Daerah atau swasta karena insidentil.

4. Taman Parkir, Taman parkir adalah suatu area bangunan perparkiran yang dilengkapi dengan fasilitas sarana perparkiran yang pengelolaannya diselenggarakan oleh Pemerintah Daerah.

5. Gedung Parkir, Gedung Parkir adalah bangunan yang dimanfaatkan untuk tempat parkir kendaraan yang penyelenggaraannya oleh Pemerintah Daerah atau pihak yang mendapat ijin dari Pemerintah Daerah.

\section{PENGENDALIAN PARKIR}

Salah satu kebijakan parkir adalah menerapkan pembatasan kegiatan parkir. Pembatasan kegiatan parkir dilakukan terhadap parkir di pinggir jalan yang ditetapkan terutama di jalan-jalan utama pusat kota. Kebijakan ini akan sangat efektif untuk meningkatkan tingkat pelayanan jaringan jalan atau untuk menyeimbangkan antara permintaan dan pembayaran kembali atas investasi keuangan untuk pembangunan prasarana dan perawatan fasilitas yang ada (Direktorat Jendral Perhubungan Darat, 1995).

Pada umumnya semakin searah dengan pergerakan menuju pusat kota akan semakin banyak menemukan hambatan-hambatan. Sejauh 
ini, aspek yang dibahas dari pengendalian parkir adalah dengan orientasi komersil. Sedangkan dari pengendalian parkir itu sendiri adalah (Direktorat Jendral Perhubungan Darat, 1998).

1. Mencegah terjadinya hambatan arus kendaraan.

2. Mengurangi kecelakaan.

3. Membuat penggunaan tempat parkir menjadi lebih efektif.

4. Memelihara benda sejarah, sekira berada di suatu kota dengan nilaisejarah yang tinggi.

5. Bertindak sebagai mekanisme pembatas terhadap penggunaan jalan di daerah yang padat.

\section{E. SATUAN RUANG PARKIR (SRP)}

Satuan ruang parkir (SRP) adalah tempat untuk satu ukuran efektif untuk meletakkan kendaraan termasuk ruang bebas dan lebhar bukaan. SRP Digunakan untuk menghitung kebutuhan ruang parkir yang dipengaruhi oleh lebar, panjang total kendaraan, jarak ruang bebas untuk kendaraan (Pedoman Teknis Penyelenggaraan Fasilitas Parkir tahun 1996). Penentuan satuan ruang parkir (SRP) didasarkan atas hal berikut:

1. Dimensi kendaraan standar untuk mobil penumpang

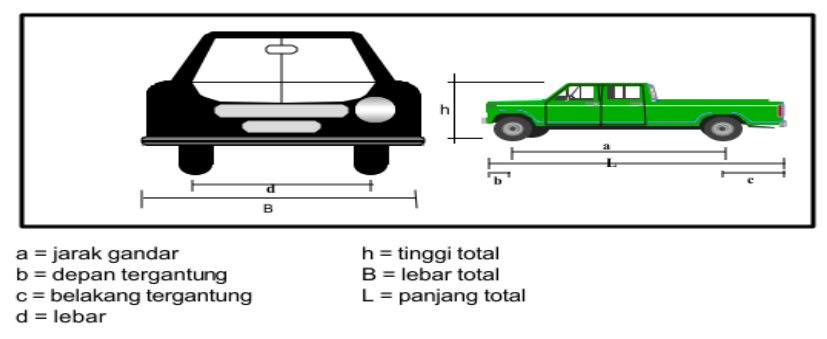

Gambar 1. Dimensi standar mobil penumpang
Penentuan satuan ruang parkir (SRP) dibagi atas tiga jenis seperti pada tabel dibawah

Tabel 1. Penentuan Satuan Ruang Parkir

\begin{tabular}{|l|c|}
\hline \multicolumn{1}{|c|}{ Jenis Kendaraan } & $\begin{array}{c}\text { Satuan Ruang } \\
\text { Parkir }\left(\mathrm{m}^{2}\right)\end{array}$ \\
\hline $\begin{array}{l}\text { 1.a. Mobil penumpang untuk } \\
\text { golongan I }\end{array}$ & $2,30 \times 5,00$ \\
\hline $\begin{array}{l}\text { 1.b. Mobil penumpang untuk } \\
\text { golongan II }\end{array}$ & $2,50 \times 5,00$ \\
\hline $\begin{array}{l}\text { 1.c. Mobil penumpang untuk } \\
\text { golongan III }\end{array}$ & $3,00 \times 5,00$ \\
\hline $\begin{array}{l}\text { 2. Bus/truk } \\
\text { 3. Sepeda Motor }\end{array}$ & $3,40 \times 12,50$ \\
\hline
\end{tabular}

(Sumber: Direktorat Jendral Perhubungan Darat, 1996)

Dalam penelitian ini besar satuan ruang parkir untuk jenis kendaraan yang akan dianalisa yaitu mobil penumpang untuk golongan II dan sepeda motor.

1. Satuan Ruang Parkir untuk mobil penumpang golongan I.

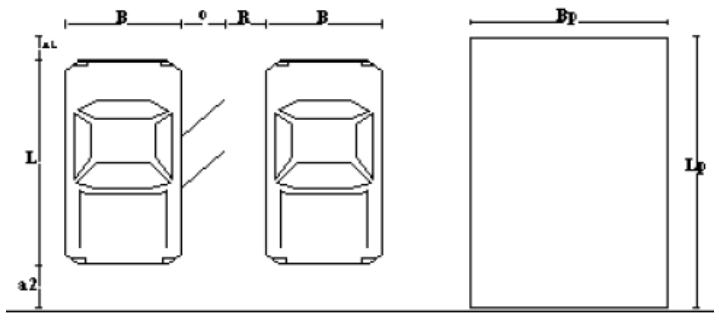

Gambar 2. SRP mobil penumpang gol II

(Sumber: Direktorat Jendral Perhubungan Darat, 1996)

Keterangan:

B = lebar total kendaraan

$\mathrm{L}=$ panjang total kendaraan

$\mathrm{O}=$ lebar bukaan pintu

a1, a2 = jarak bebas arah longitudinal

$\mathrm{R} \quad=$ jarak bebas arah lateral 
Gol II: B $=170$

$$
\begin{array}{ll}
\mathrm{a} 1 & =10 \\
\mathrm{Bp} & =250=\mathrm{B}+\mathrm{O}+\mathrm{R} \\
\mathrm{O} & =75 \\
\mathrm{~L} & =470 \\
\mathrm{Lp} & =500=\mathrm{L}+\mathrm{a} 1+\mathrm{a} 2 \\
\mathrm{R} & =5
\end{array}
$$

2. Satuan Ruang Parkir untuk sepeda motor

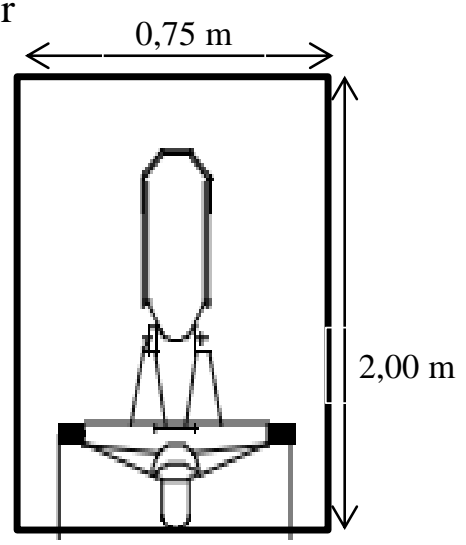

Gambar 3 SRP sepeda motor

(Sumber: Direktorat Jendral Perhubungan Darat, 1996)

\section{F. KEBUTUHAN RUANG PARKIR}

Ukuran kebutuhan ruang parkir akan berbeda beda untuk tiap jenis tempat kegiatan. Hal ini disebabkan antara lain karena perbedaan tipe pelayanan, tariff yang dikenakan, ketersediaan ruang parkir, tingkat kepemilikan kendaraan bermotor, dan tingkat pendapatan masyarakat. Menurut Direktorat Jendral Perhubungan Darat 1996, standar kebutuhan ruang parkir untuk pusat perbelanjaan bisa dilihat dalam Tabel 2 dan 3.
Tabel 2. Kebutuhan SRP di Pusat Perdagangan

\begin{tabular}{|c|c|c|c|c|c|c|c|c|}
\hline $\begin{array}{c}\text { Luas Area } \\
\text { Total }\left(100 \mathrm{~m}^{2}\right)\end{array}$ & 10 & 20 & 50 & 100 & 500 & 1000 & 1500 & 2000 \\
\hline $\begin{array}{c}\text { Kebutuhan } \\
(\mathrm{SRP})\end{array}$ & 59 & 67 & 88 & 125 & 415 & 777 & 1140 & 1502 \\
\hline
\end{tabular}

\begin{tabular}{|c|c|c|}
\hline Peruntukan & $\begin{array}{l}\text { Satuan (SRP } \\
\text { untuk mobil } \\
\text { penumpang) }\end{array}$ & $\begin{array}{c}\text { Kebutuhan } \\
\text { Ruang } \\
\text { Parkir }\end{array}$ \\
\hline \multirow{2}{*}{\multicolumn{3}{|c|}{$\begin{array}{l}\text { Pusat } \\
\text { Perdagangan }\end{array}$}} \\
\hline & & \\
\hline a) Pertokoan & $\begin{array}{c}\mathrm{SRP} / 100 \mathrm{~m}^{2} \text { luas } \\
\text { lantai efektif }\end{array}$ & $3,5-7,5$ \\
\hline b) Pasar & & $3,5-7,5$ \\
\hline Swalayan & lantai efektif & \\
\hline c) Pasar & $\begin{array}{c}\mathrm{SRP} / 100 \mathrm{~m}^{2} \text { luas } \\
\text { lantai efektif }\end{array}$ & \\
\hline \multicolumn{3}{|l|}{ Pusat Perkantoran } \\
\hline $\begin{array}{l}\text { a. Pelayanan } \\
\text { bukan } \\
\text { umum }\end{array}$ & $\begin{array}{c}\mathrm{SRP} / 100 \mathrm{~m}^{2} \text { luas } \\
\text { lantai efektif }\end{array}$ & $1,5-3,5$ \\
\hline $\begin{array}{l}\text { b. Pelayanan } \\
\text { umum }\end{array}$ & $\begin{array}{c}\mathrm{SRP} / 100 \mathrm{~m}^{2} \text { luas } \\
\text { lantai efektif }\end{array}$ & \\
\hline Sekolah & $\mathrm{SRP} /$ mahasiswa & $0,7-1,0$ \\
\hline $\begin{array}{l}\text { Hotel/Tempat } \\
\text { Penginapan }\end{array}$ & SRP/kamar & $0,2-1,0$ \\
\hline Rumah Sakit & SRP/tempat tidur & $0,2-1,3$ \\
\hline Bioskop & $\begin{array}{l}\text { SRP/tempat } \\
\text { duduk }\end{array}$ & $0,1-0,4$ \\
\hline
\end{tabular}

(Sumber: Direktorat Jendral Perhubungan Darat, 1996)

Berdasarkan ukuran ruang parkir yang dibutuhkan yang belum tercakup dalam tabel di atas bisa dicari dengan tabel di bawah.

Tabel 3. Kebutuhan Ruang Parkir

(Sumber: Direktorat Jendral Perhubungan Darat, 1996) 


\section{G. KARAKTERISTIK PARKIR}

Karakteristik parkir adalah parameter yang dipakai untuk melakukan analisis kondisi operasional dan juga perencanaan lahan parkir. Untuk mengetahui karakteristik parkir yang harus diketahui adalah:

1. Akumulasi Parkir, Akumulasi Parkir adalah jumlah kendaraan yang berada diparkir di suatu ara pada waktu tertentu (Suwardi, 2000). Menurut Direktorat Jendral Perhubungan Darat (1998), akumulasi parkir adalah total jumlah kendaraan yang diparkir, di suatu daerah pada saat tertentu. Dapat dicari mengunakan rumus:

$$
\text { Akumulasi parkir }=E i-E x
$$

Jika ada kendaraan yang sudah parkir sebelum dilakukan pengamatan, maka dihitung menggunakan rumus:

$$
\text { Akumulasi parkir }=E i-E x+X
$$

\section{Keterangan:}

$$
\begin{aligned}
& \mathrm{Ei}=\text { Masuk (Kendaraan yang masuk) } \\
& \mathrm{Ex}=\text { Keluar (Kendaraan yang keluar) } \\
& \mathrm{X}=\text { Jumlah kendaraan sebelumnya }
\end{aligned}
$$

Dari hasil yang diperoleh dibuat grafik yan menunjukan persentase kendaraan dalam kurva akumulasi karakteristik.

2. Volume Parkir, Volume Parkir adalah jumlah kendaraan yang terlibat dalam suatu ara parkir (Suwardi, 2000). Menurut Direktorat Jendral Perhubungan Darat (1998), volume parkir adalah jumlah seluruh kendaraan yang menggunakan fasilitas parkir. (kendaraan - kendaraan perperiode waktu tertentu, biasanya perhari). Volume parkir dihitung dengan menjumlahkan kendaraan yang menggunakan area parkir dalam waktu satu hari dengan menggunakan rumus:

$$
\text { Volume parkir }=\mathrm{Ei}+\mathrm{x}
$$

Keterangan:

$$
\begin{aligned}
& \mathrm{Ei}=\text { Masuk (Kendaraan yang masuk) } \\
& \mathrm{x}=\text { Jumlah kendaraan sebelumnya }
\end{aligned}
$$

3. Indeks Parkir, Indeks parkir adalah persentase jumlah tempta parkir tersedia dengan jumlah kendaraan parkir yang menempati (Hobbs, 1995),

Menurut Suwardi (2000), Indeks parkir adalah ukuran untuk menyatakan penggunaan panjang jalan dan dinyatakan dalam presentase ruan yan ditempati oleh kendaraan parkir pada tiap panjang 6 meter yan tersedia. Indeks parkir dapat dicari dengan rumus:

Indeks Parkir $=\frac{\text { Akumulasi Parkir }}{\text { Ruang parkir yang tersedia }} \times 100 \%(5)$

4. Tingkat Turnover adalah tingkat penggunaan ruang parkir (Hobbs, 1979). Tingkat Turnover bisa dikakalkulasikan dengan membatasi total jumlah jam kendaraan untuk periode pengamatan dengan jumlah ruang parkir tertentu, dapat dicari dengan rumus:

$$
\text { Turnover }=\frac{\text { Volume parkir }}{\text { ruang parkir yang tersedia }}
$$


5. Kebutuhan Ruang Parkir, Kebutuhan ruang parkir (KRP) dapat dicari dengan rumus yang ada di Dirjen perhubungan Darat.

$$
\mathrm{KRP}=\mathrm{F} 1 \times \mathrm{F} 2 \times \mathrm{VPH}
$$

(sumber: Studi Kriteria Perencangan dan Kebutuhan Ruang Parkir pada Pusat-pusat Kegiatan, LPM UGM 1992)

\section{METODE PENELITIAN}

\section{A. LOKASI PENELITIAN}

Lokasi Studi yang akan dianalisis kebutuhan ruang parkirnya dipilih di pusat perbelanjaan Mall Solo Square yang merupakan salah satu pusat perbelanjaan besar yang berada di jalan Brigjend Slamet Riyadi No. 451-455, Pajang, Laweyan, Kota Surakarta, Jawa Tengah. Jumlah SRP untuk mobil penumpang yang disediakan pihak pengelola parkir mall Solo Square dari hasil wawancara dengan pihak terkait ada sekitar 548 SRP untuk mobil golongan I, dan untuk sepeda motor ada 758 SRP Berikut gambar lokasi studi:

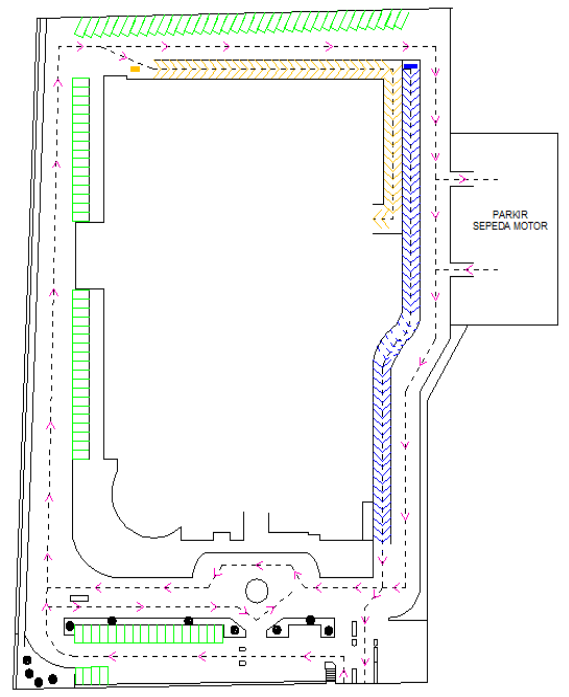

Gambar 4. Denah Lokasi Penelitian

\section{B. WAKTU PENELITIAN}

Waktu yang dipilih untuk pelaksanaan survei dan melakukan wawancara dengan pengelola lahan parkir, Berikut hari yang ditentukan untuk pelaksanaan survei:

1. Survei pada hari Jumat 22 Maret 2019, pengumpulan data dliakukan selama 12 jam $(10.00-22.00 \mathrm{WIB})$.

2. Survei pada hari Sabtu 23 Maret 2019, pengumpulan data dilakukan selama 12 jam $(10.00-22.00 \mathrm{WIB}$

3. Survei pada hari Minggu 24 Maret 2019, pengumpulan data dilakukan selama 12 jam $(10.00-22.00 \mathrm{WIB})$.

\section{ANALISA DAN PEMBAHASAN}

\section{A. HASIL PENGUMPULAN DATA}

Jenis kendaraan yang parkir terdiri dari:

1. Mobil penumpang (golongan II) dan Sepeda Motor.

2. Luas arel parkir seluruhnya sebesar 19797 $\mathrm{m}^{2}$, terdiri dari:
a. Luas parkir sepeda motor $=2365 \mathrm{~m}^{2}$
b. Luas parkir mobil $=17432 \mathrm{~m}^{2}$

3. SRP untuk mobil golongan $\mathrm{II}=(2,50 \times 5,00)$ $\mathrm{m}^{2}=12,5 \mathrm{~m}^{2} /$ kendaraan

4. SRP untuk sepeda motor $=(0,75 \times 2,00) \mathrm{m}^{2}$ $=1,5 \mathrm{~m}^{2} /$ kendaraan

5. Model parkir dan kapasitas parkir terdiri dari:

a. Jenis kendaraan golongan II dengan pola parkir dua sisi dengan sudut $45^{\circ}$ kapasitas tersedia 100 kendaraan. 
b. Jenis kendaraan golongan II dengan pola parkir pulau dengan sudut $90^{\circ}$ kapasitas tersedia 448 kendaraan.

\section{B. KARAKTERISTIK PARKIR}

1. Akumulasi Parkir

Hasil akumulasi maksimum harian kendaraan di Mall Solo Square dapat dilihat pada tabel 4 . Sedangkan grafiknya dapat dilihat pada gambar 5 untuk mobil penumpang dan gambar 6 untuk sepeda motor.

Tabel 4. Akumulasi maksimum harian kendaraan

\begin{tabular}{|c|c|c|c|c|c|c|c|c|c|}
\hline \multirow[b]{2}{*}{ Waktu } & \multirow[b]{2}{*}{ HariTgl } & \multicolumn{4}{|c|}{ Mobil } & \multicolumn{4}{|c|}{ Sepeda Motor } \\
\hline & & $\begin{array}{c}\text { Jam } \\
\text { puncak }\end{array}$ & $\begin{array}{c}\text { Akumulasi } \\
\text { maks }\end{array}$ & Kapasitas & $\begin{array}{l}\text { Rata- } \\
\text { rata }\end{array}$ & $\begin{array}{c}\text { Jam } \\
\text { puncak }\end{array}$ & $\begin{array}{c}\text { Akumulasi } \\
\text { maks }\end{array}$ & Kapasitas & $\begin{array}{c}\text { Rata. } \\
\text { rata }\end{array}$ \\
\hline \multirow{3}{*}{$\begin{array}{c}10: 00 \\
- \\
22: 00\end{array}$} & $\begin{array}{c}\text { Jumat, } \\
22 \\
\text { Maret } \\
2019 \\
\end{array}$ & $\begin{array}{l}19: 16- \\
19: 30\end{array}$ & 314 & 548 & 457 & $\begin{array}{l}19: 16- \\
19: 30\end{array}$ & 597 & 758 & 698 \\
\hline & $\begin{array}{l}\text { Sabtu, } \\
23 \\
\text { Maret } \\
2019\end{array}$ & $\begin{array}{c}18: 31- \\
18: 45 \\
\& \\
18: 46- \\
19: 00\end{array}$ & 416 & 548 & 457 & $\begin{array}{l}18: 46- \\
19: 00\end{array}$ & 637 & 758 & 698 \\
\hline & $\begin{array}{c}\text { Minggu, } \\
24 \mathrm{April} \\
2019\end{array}$ & $\begin{array}{c}16: 16- \\
16: 30 \\
\& \\
16: 46- \\
17: 00\end{array}$ & 595 & 548 & 457 & $\begin{array}{l}15: 16- \\
15: 30\end{array}$ & 852 & 758 & 698 \\
\hline
\end{tabular}

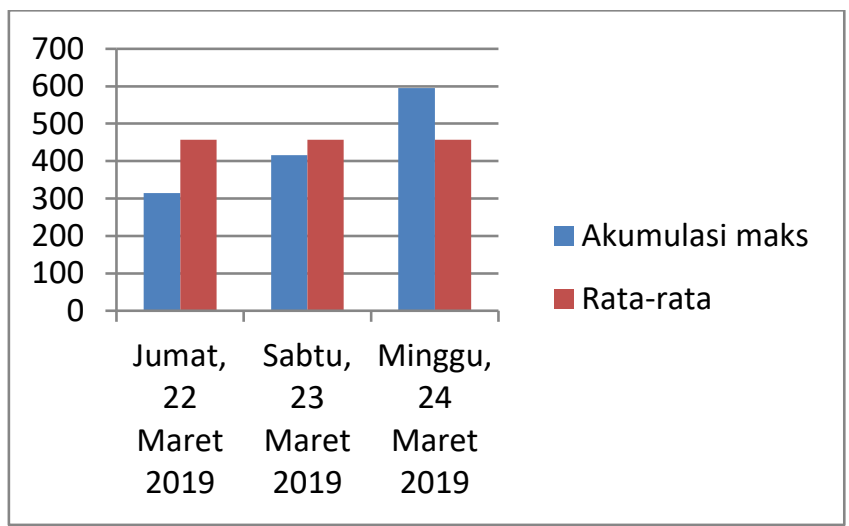

Gambar 5. Grafik akumulasi maksimum mobil

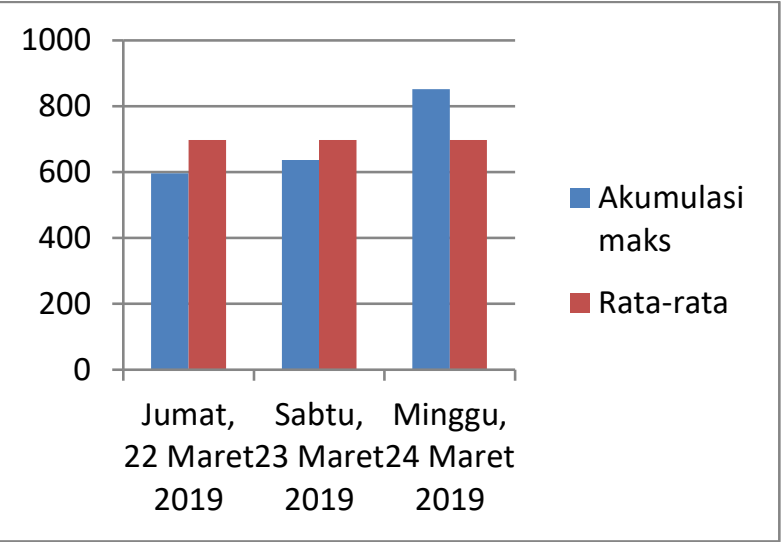

Gambar 6. Grafik akumulasi maksimum sepeda motor Berdasarkan Tabel 4 dan Gambar 5 dapat dilihat bahwa.

a. Akumulasi maksimum parkir untuk mobil penumpang pada jam10:00 - 22:00 WIB.

1) Akumulasi maksimum tertinggi terjadi pada hari minggu tanggal 24 Maret 2019 yaitu dengan jumlah 595 kendaraan.

2) Kondisi ini berada di atas kapasitas parkir mobil penumpang di Mall Solo Square yaitu 548 kendaraan.

b. Akumulasi maksimum parkir untuk sepeda motor pada jam10:00-22:00 WIB

1) Akumulasi maksimum tertinggi terjadi pada hari minggu tanggal 24 Maret 2019 yaitu dengan jumlah 852 kendaraan.

2) Kondisi ini berada di atas kapasitas parkir mobil penumpang di Mall Solo Square yaitu 758 kendaraan.

2. Volume Parkir

Volume parkir hasil pengamatan selama tiga hari tersebut dapat dilihat pada Tabel 5. 
Tabel 5 Volume parkir harian kendaraan selama 3 hari pengamatan

\begin{tabular}{|c|c|c|c|c|c|}
\hline \multirow{3}{*}{ Hari/Tgl } & \multirow{3}{*}{ Waktu } & \multicolumn{4}{|c|}{$\begin{array}{l}\text { Volume Parkir satu hari (kendaraan/12 } \\
\text { jam) }\end{array}$} \\
\hline & & \multicolumn{2}{|c|}{ Mobil } & \multicolumn{2}{|c|}{ Sepeda Motor } \\
\hline & & $\begin{array}{l}\text { Volume } \\
\text { Parkir }\end{array}$ & \begin{tabular}{|c|} 
Kapasitas \\
Parkir \\
\end{tabular} & $\begin{array}{l}\text { Volume } \\
\text { Parkir }\end{array}$ & \begin{tabular}{|c|} 
Kapasitas \\
Parkir \\
\end{tabular} \\
\hline Jumat, 22 Maret 2019 & $10: 00-22: 00$ & 1119 & 548 & 1929 & 758 \\
\hline Sabtu, 23 Maret 2019 & $10: 00-22: 00$ & 1661 & 548 & 2421 & 758 \\
\hline Minggu, 24 Maret 2019 & $10: 00-22: 00$ & 1970 & 548 & 2793 & 758 \\
\hline Total & & 4750 & & 7143 & \\
\hline Rata-rata & & 1583 & & 2381 & \\
\hline
\end{tabular}

3. Indeks Parkir

Besarnya Indeks parker dapat dilihat pada gambar 7 dan gambar 8, untuk masing masing indeks parkir mobil golongan II dan sepeda motor dipisahkan seperti [ada grafik dibawah ini:

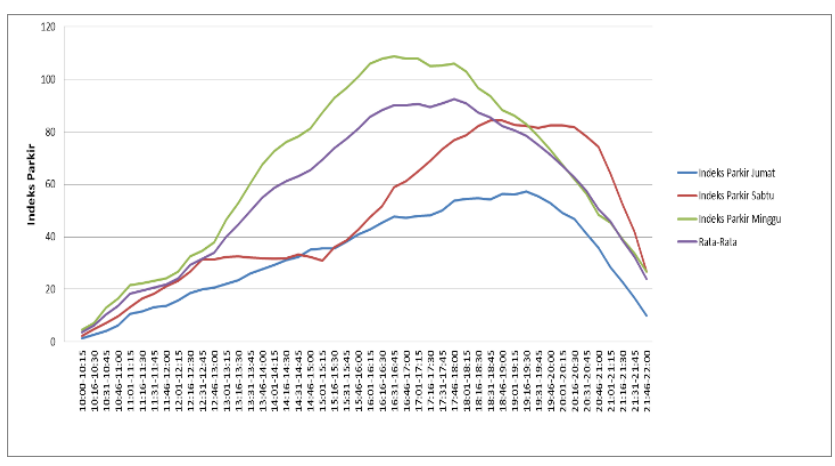

Gambar 7. Grafik besarnya Indeks parkir untuk mobil golongan II

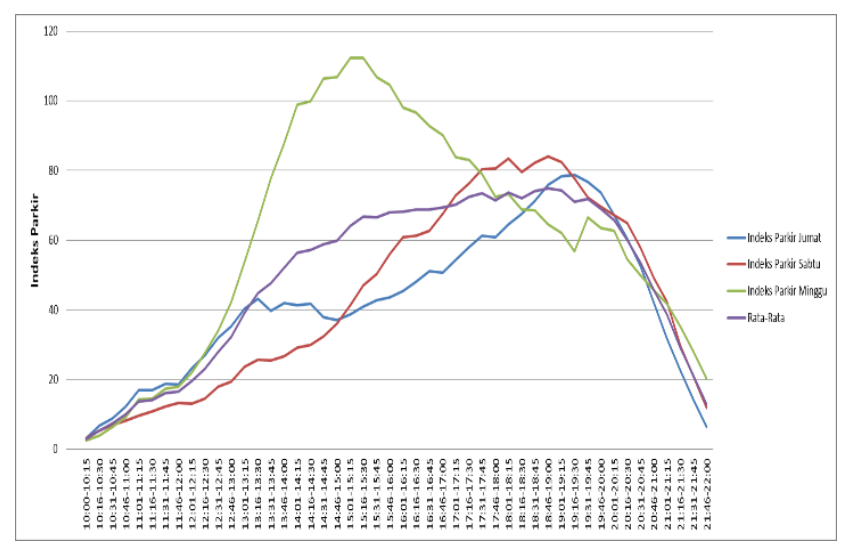

Gambar 8. Grafik besarnya Indeks parkir untuk Sepeda Motor
Berdasarkan hasil pengamatan pada gambar grafik dan gambar grafik 4.2, didapatkan hasil sebagai berikut:

a. Indeks parkir mobil penumpang maksimal tertingi selama tiga hari pengamatan terjadi pada hari Minggu tanggal 24 Maret 2019 dengan indeks parkir sebesar 108,58\%.

b. Indeks parkir sepeda motor maksimal tertingi selama tiga hari pengamatan terjadi pada hari Minggu tanggal 24 Maret 2019 dengan indeks parkir sebesar 112,40\%.

\section{Turnover}

Berdasarkan tabel Volume harian dan jumlah ruang parkir yang tersedia dapat diperoleh angka turnover parkir dalam periode waktu tertentu yang terdapat dalam Tabel 6

Tabel 6. Tingkat Turnover

\begin{tabular}{|c|l|r|r|r|}
\hline Jenis Kendaraan & Hari/Tanggal & $\begin{array}{c}\text { Volume } \\
\text { Parkir }\end{array}$ & Kapasitas & $\begin{array}{c}\text { Turnover } \\
\text { kend/hari/ruang) }\end{array}$ \\
\hline \multirow{3}{*}{ Mobil Penumpang } & Sumat, 22 Maret 2019 & 1119 & 548 & 2.04 \\
\cline { 2 - 5 } & Mabtu, 23 Maret 2019 & 1661 & 548 & 3.03 \\
\hline Rata-Rata & & & & 3.59 \\
\hline \multirow{3}{*}{ Sepeda Motor } & Jumat, 22 Maret 2019 & 1929 & 758 & 2.89 \\
\cline { 2 - 5 } & Sabtu, 23 Maret 2019 & 2421 & 758 & 2.54 \\
\cline { 2 - 5 } & Minggu, 24Maret 2019 & 2793 & 758 & 3.19 \\
\hline Rata-Rata & & & & 3.68 \\
\hline
\end{tabular}

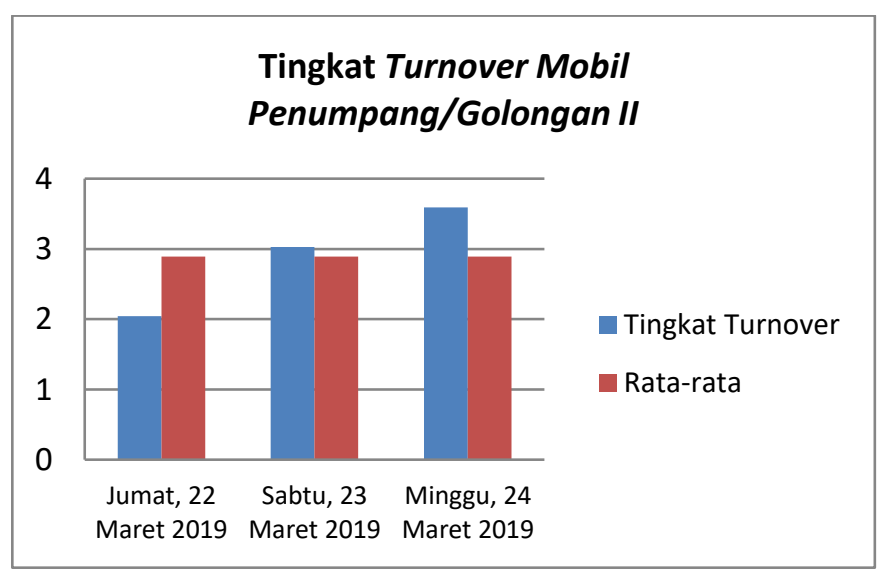

Gambar 9. Grafik Tingkat Turnover Mobil Golongan II 


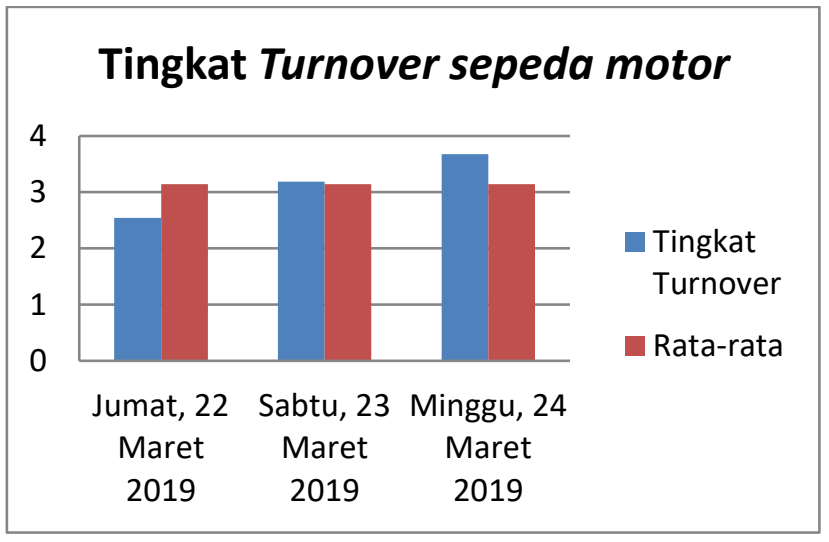

Gambar 10. Grafik Tingkat Turnover Sepeda Motor

Berdasarkan gambar 9 dan gambar 10 dapat diketahui bahwa:

a. Tingkat Turnover tertinggi untuk mobil penumpang pada hari Minggu, 24 Maret 2019 sebesar 3,59 kend/hari/ruang, Hari sabtu sebesar 3,03 kend/hari/ruang, pada hari Jumat, sebesar 2,04 kend/hari/ruang. Rata-rata tingkat turnover untuk mobil penumpang sebesar 2,89 kend/hari/ruang.

b. Tingkat Turnover untuk sepeda motor pada hari Minggu, 24 Maret 2019 sebesar 3,68

c. kend/hari/ruang, hari Sabtu, 23 Maret 2019 sebesar 3,19 kend/hari/ruang, hari Jumat, 22 Maret 2019 sebesar 2,54 kend/hari/ruang , Rata-rata tingkat turnover untuk sepeda motor dari tiga hari pengamatan sebesar 2,14 kend/hari/ruang.

\section{Durasi Parkir}

Durasi Parkir adalah lamanya waktu yang dibutuhkan kendaraan parkir di area parkir (F.D. Hobbs, 1979). Durasi parkir dapat dihitung menggunakan rumus sebagai beikut:

$$
\begin{gathered}
d=\frac{m-x_{0}}{i} \\
\bar{x}=x_{0}+\left[\frac{\sum f_{1} \cdot d}{\sum f_{1}}\right] \cdot i \\
\mathrm{SD}=i \cdot \sqrt{\frac{\sum f_{1} \cdot d^{2}}{n}-\left[\frac{\sum f_{1} \cdot d}{n}\right]^{2}}
\end{gathered}
$$

(sumber: Metode Statika, Sudjana, 1986)

Besarnya durasi parkir pada penelitian ini dapat dilihat pada gambar 11 dan gambar 12

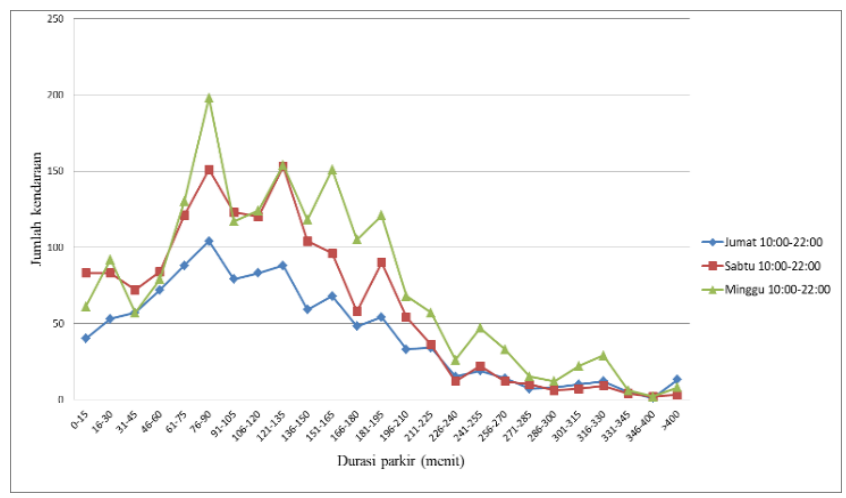

Gambar 11. Grafik durasi parkir mobil golongan II

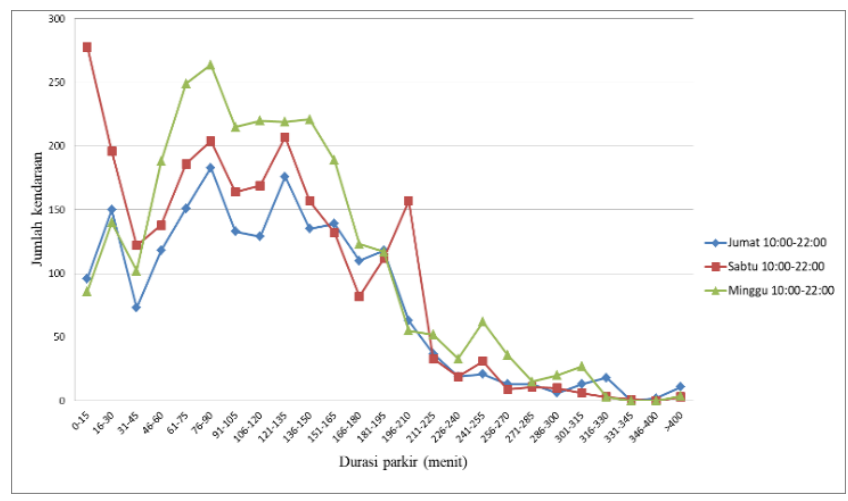

Gambar 12. Grafik durasi parkir sepeda motor Berdasarkan gambar diatas dapat diketahui bahwa: a. Gambar 11 adalah grafik durasi parkir mobil golongan II yang disusun dari tabel durasi dapat dilihat jumlah mobil tertinggi hari Jumat 
terjadi pada durasi 76 - 90 menit dengan jumlah mobil 104 kendaraan, hari Sabtu terjadi pada durasi 121 - 135 menit dengan jumlah mobil 153 kendaraan, hari Minggu terjadi pada durasi 76 - 90 menit dengan jumlah mobil 198 kendaraan.

b. Gambar 12 adalah grafik durasi parkir sepeda motor yang disusun dari tabel durasi parkir, Dari grafik ini dapat dilihat jumlah sepeda motor tertinggi pada hari Jumat terjadi pada durasi 76 - 90 menit dengan jumlah mobil 183 kendaraan, hari Sabtu terjadi pada durasi 0 - 15 menit dengan jumlah mobil 278 kendaraan, hari Minggu terjadi pada durasi 76 - 90 menit dengan jumlah mobil 264 kendaraan.

\section{KEBUTUHAN RUANG PARKIR}

Untuk mengetahui kebutuhan ruang parkir di suatu tempat kegiatan diperlukan data. Data-data yang harus ada adalah akumulasi mksimum yang terjadi, volume parkir harian dan luas areal parkir. Berdasarkan studi literature dan data di lapangan seperti data akumulasi mobil dan sepeda motor diperoleh factor akumulasi (F1) dan daktor fluktuasi (F2), telah dilakukan perhitungan. yaitu distribusi arus lalu lintas masuk dan keluar ruang parkir secara jam-jaman bagi mobil dan sepeda motor.

Luas area parkir yang dibutuhkan secara teoritis adalah:

1. Mobil Golongan II

$$
\mathrm{KRP}=478,857 \mathrm{SRP}, \text { Kapasitas }=548 \mathrm{SRP}
$$

$$
\mathrm{LKPR}=478,857 \times 12,5=5986 \mathrm{~m}^{2}
$$

Luas areal parkir mobil $=\frac{K R P X L K P R}{\text { Kapasitas }}$

$$
\begin{aligned}
& =\frac{478,857 \times 5986}{548} \\
& =5230,726 \mathrm{~m} 2
\end{aligned}
$$

2. Sepeda Motor

$$
\mathrm{KRP}=735,639 \mathrm{SRP},
$$

Kapasitas $=758$ SRP

$$
\begin{aligned}
& \text { LKPR }=735,639 \times 1,5=1104 \mathrm{~m}^{2} \\
& \begin{aligned}
\text { Luas areal parkir mobil } & =\frac{\text { KRP } X \text { LKPR }}{\text { Kapasitas }} \\
& =\frac{735,639 \times 1104}{758} \\
& =1071,432 \mathrm{~m}^{2}
\end{aligned}
\end{aligned}
$$

Dari perhitungan toritis di atas diperoleh kebutuhan ruang parkir sebagai berikut:

1. Kebutuhan ruang parkir mobil adalah 478,857 SRP dengan luas areal parkir $5230,726 \mathrm{~m}^{2}$.

2. Kebutuhan ruang parkir sepeda motor adalah 735,639 SRP dengan luas areal parkir $1071,432 \mathrm{~m}^{2}$.

3. Luas areal parkir total yan dibutuhkan $6302,158 \mathrm{~m}^{2}$

Sedangkan untuk kenyataan di lapangan, luas areal parkir yang dibutuhkan adalah:

1. Luas area parkir mobil

= Akumulasi maks x SRP mobil Gol. II

$=595 \times 12,5 \mathrm{~m}^{2}$

$=7437,5 \mathrm{~m}^{2}$

2. Luas area parkir motor = Akumulasi maks x SRP sepeda motor 


$$
\begin{aligned}
& =852 \times 1,5 \mathrm{~m}^{2} \\
& =1278 \mathrm{~m}^{2}
\end{aligned}
$$

Dari perhitungan di atas diperoleh kebutuhan ruang parkir sebagai berikut:

a) Kebutuhan ruang parkir mobil adalah 478,857 SRP dengan luas areal parkir $5230,726 \mathrm{~m}^{2}$

b) Kebutuhan ruang parkir sepeda motor adalah 735,639 SRP dengan luas areal parkir $1071,432 \mathrm{~m}^{2}$

c) Luas areal parkir total yan dibutuhkan $6302,158 \mathrm{~m}^{2}$

Dari perhitungan di atas dapat dilihat bahwa kebutuhan ruang parkir yang ada di Mall Solo Square masih memenuhi standar kebutuhan ruang parkir untuk pusat perdagangan yang telah ditetapkan oleh Direktorat Jendral Perhubungan Darat, 1998. Yaitu untuk luas bangunan sebesar $25200 \mathrm{~m}^{2}$, dibutuhkan satuan ruang parkir minimal 882 SRP dan maksimal sebesar 1890 SRP. Sedangkan pada kenyataan di lapangan total kebutuhan ruang parkir yang tersedia adalah sebesar 1306 SRP.

\section{KESIMPULAN}

Berdasarkan hasil survei dan analisis data yang dilakukan, dapat ditemukan beberapa kesimpilan yang berkaitan dengan kebutuhan dan kapasitas parkir di Mall Solo Square sebagai berikut:

1. Akumulasi parkir kendaraan maksimum untuk mobil penumpang terjadi pada hari Minggu yaitu dengan 595 kend melebihi ruang parkir yang tersedia yaitu 548 kend, serta untuk sepeda motor terjadi pada hari Minggu sebesar 852 kend dan itu melebihi ruang parkir yang tersedia yaitu 758 kend

2. Volume parkir harian untuk mobil penumpang yang paling tinggi terjadi pada hari Minggu sebanyak 1970 kend. Serta untuk sepeda motor sebanyak 2793 kend.

3. Indeks parkir tertinggi sebesar 108,58\% untuk mobil penumpang, dan sepeda motor sebesar $112,40 \%$.

4. Rata-rata tingkat turnover untuk mobil penumpang dan sepeda motor untuk tiga hari survei yang dilakukan didapat 2,89 kend/hari/ruang untuk mobil penumpang, dan 2,14 kend/hari/ruang untuk sepeda motor.

5. Durasi parkir yang tertinggi untuk mobol golongan II sebesar 77,108 menit. Serta untuk sepeda motor 70,644 menit.

6. Kebutuhan ruang parkir untuk mobil penumpang dan sepeda motor adalah 478,857 SRP masih bisa ditampung karena tersedia 548 SRP, untuk sepeda motor adalah 735,639 SRP masih bisa ditampung karena tersedia 758 SRP.

7. Luas kebutuhan ruang parkir yang dibutuhkan secara teoritis didapatkan 5230,726 $\mathrm{m}^{2}$ untuk mobil, dan 1071,432 $\mathrm{m}^{2}$ untuk sepeda motor, dengan demikian didapat total luas area parkir yang dibutuhkan $6302,158 \mathrm{~m}^{2}$

8. Luas area parkir yang dibutuhkan di lapangan untuk mobil penumpang dan sepeda motor didapat 7437,5 $\mathrm{m}^{2}$ untuk mobil penumpang dan $1278 \mathrm{~m}^{2}$ untuk sepeda motor. Luas area parkir yang tersedia $17432 \mathrm{~m}^{2}$ untuk mobil 
penumpang dan $2365 \mathrm{~m}^{2}$ untuk sepeda motor. Jadi luas area parkir yang tersedia di Mall Solo Square masih bisa mencukupi luas parkir yang dibutuhkan.

9. Analisis antara ketersediaan kebutuhan dengan ketersediaan area parkir di Mall Solo Square masih bisa menampung jumlah kendaraan pengunjung yang datang.

\section{DAFTAR PUSTAKA}

Anindia, Ismira, 2003. Studi Tarif Dasar Parkir Sebagai Upaya Pengelolaan Parkir di Kawasan Pusat Kota Bandung, Skripsi, Departemen Teknik Planologi, ITB. Bandung.

Anonim, 1992, Studi Kriteria Perencanaan dan Kebutuhan Ruang Parkir pada Pusat-Pusat Kegiatan (Off Street Parking), Departemen Pendidikan dan Kebudayaan Pusat Pengembangan Teknologi Tepat Lembaga Pengabdian Masyarakat.

Anonim, 1998, Pedoman Perencanaan dan Pengoperasian Fasilitas Parkir, Direktorat Jenderal Perhubungan Darat Jakarta.

BAPPEDA, 1995, Studi Penelitian dan Pengkajian Jaringan Transportasi Kota Surakarta. Kantor BAPPEDA Kota Surakarta, Surakarta.

Hobbs, 1979, Perencanaan dan Teknik Lalu Lintas, UGM Press, Yogyakarta.

Sudjana, 1988, Metode Statistika, Tarsito, Bandung.

The World Bank, 1986. Urban Transport.
Warpani, S, 1990, Merencanakan Sistem Transportasi, ITB, Bandung. 